\title{
Production of peroxy nitrates in boreal biomass burning plumes over Canada during the BORTAS campaign
}

\author{
Marcella Busilacchio $^{1}$, Piero Di Carlo ${ }^{1,2}$, Eleonora Aruffo ${ }^{1,2}$, Fabio Biancofiore ${ }^{1,2}$, Cesare Dari Salisburgo ${ }^{1}$, \\ Franco Giammaria ${ }^{2}$, Stephane Bauguitte ${ }^{3}$, James Lee ${ }^{4}$, Sarah Moller ${ }^{4}$, James Hopkins ${ }^{4}$, Shalini Punjabi ${ }^{4}$, \\ Stephen Andrews ${ }^{4}$, Alistair C. Lewis ${ }^{4}$, Mark Parrington ${ }^{5, a}$, Paul I. Palmer ${ }^{5}$, Edward Hyer ${ }^{6}$, and Glenn M. Wolfe ${ }^{7,8}$ \\ ${ }^{1}$ Center of Excellence CETEMPS, University of L'Aquila, Via Vetoio, Coppito, L'Aquila, Italy \\ ${ }^{2}$ Department of Physical and Chemical Sciences, University of L'Aquila, Coppito, L'Aquila, Italy \\ ${ }^{3}$ Facility for Airborne Atmospheric Measurements, Bedfordshire, UK \\ ${ }^{4}$ Department of Chemistry, University of York, York, UK \\ ${ }^{5}$ School of GeoSciences, University of Edinburgh, Edinburgh, UK \\ ${ }^{6}$ Marine Meteorology Division, Naval Research Laboratory, Monterey, California, USA \\ ${ }^{7}$ Atmospheric Chemistry and Dynamics Laboratory, NASA Goddard Space Flight Center, Greenbelt, Maryland, USA \\ ${ }^{8}$ Joint Center for Earth Systems Technology, University of Maryland Baltimore County, Baltimore, MD, USA \\ ${ }^{a}$ now at: European Centre for Medium-Range Weather Forecasts (ECMWF), Reading, UK
}

Correspondence to: Piero Di Carlo (piero.dicarlo@aquila.infn.it)

Received: 8 February 2015 - Published in Atmos. Chem. Phys. Discuss.: 3 March 2015

Revised: 24 December 2015 - Accepted: 19 February 2016 - Published: 17 March 2016

\begin{abstract}
The observations collected during the BOReal forest fires on Tropospheric oxidants over the Atlantic using Aircraft and Satellites (BORTAS) campaign in summer 2011 over Canada are analysed to study the impact of forest fire emissions on the formation of ozone $\left(\mathrm{O}_{3}\right)$ and total peroxy nitrates $\sum \mathrm{PNs}, \sum \mathrm{ROONO}_{2}$ ). The suite of measurements on board the BAe-146 aircraft, deployed in this campaign, allows us to calculate the production of $\mathrm{O}_{3}$ and of $\sum$ PNs, a long-lived $\mathrm{NO}_{x}$ reservoir whose concentration is supposed to be impacted by biomass burning emissions. In fire plumes, profiles of carbon monoxide (CO), which is a well-established tracer of pyrogenic emission, show concentration enhancements that are in strong correspondence with a significant increase of concentrations of $\sum \mathrm{PNs}$, whereas minimal increase of the concentrations of $\mathrm{O}_{3}$ and $\mathrm{NO}_{2}$ is observed. The $\sum \mathrm{PN}$ and $\mathrm{O}_{3}$ productions have been calculated using the rate constants of the first- and second-order reactions of volatile organic compound (VOC) oxidation. The $\sum \mathrm{PN}$ and $\mathrm{O}_{3}$ productions have also been quantified by 0 $\mathrm{D}$ model simulation based on the Master Chemical Mechanism. Both methods show that in fire plumes the average production of $\sum$ PNs and $\mathrm{O}_{3}$ are greater than in the background plumes, but the increase of $\sum \mathrm{PN}$ production is more
\end{abstract}

pronounced than the $\mathrm{O}_{3}$ production. The average $\sum \mathrm{PN}$ production in fire plumes is from 7 to 12 times greater than in the background, whereas the average $\mathrm{O}_{3}$ production in fire plumes is from 2 to 5 times greater than in the background. These results suggest that, at least for boreal forest fires and for the measurements recorded during the BORTAS campaign, fire emissions impact both the oxidized $\mathrm{NO}_{y}$ and $\mathrm{O}_{3}$, but (1) $\sum \mathrm{PN}$ production is amplified significantly more than $\mathrm{O}_{3}$ production and (2) in the forest fire plumes the ratio between the $\mathrm{O}_{3}$ production and the $\sum \mathrm{PN}$ production is lower than the ratio evaluated in the background air masses, thus confirming that the role played by the $\sum$ PNs produced during biomass burning is significant in the $\mathrm{O}_{3}$ budget. The implication of these observations is that fire emissions in some cases, for example boreal forest fires and in the conditions reported here, may influence more long-lived precursors of $\mathrm{O}_{3}$ than short-lived pollutants, which in turn can be transported and eventually diluted in a wide area. 


\section{Introduction}

Biomass burning emissions are an important atmospheric source of fine carbonaceous particles, trace gases, and aerosols that significantly affect the chemical composition of the atmosphere and the radiation balance of the Earthatmosphere system (Crutzen et al., 1979; Crutzen and Andreae, 1990; Andreae and Merlet, 2001; Bond et al., 2004; Langmann et al., 2009; Bowman et al., 2009). Biomass burning generates large quantities of carbon monoxide (CO), nitrogen oxides $\left(\mathrm{NO}_{x}=\mathrm{NO}+\mathrm{NO}_{2}\right)$, and VOCs, which are the major precursors involved in the photochemical production of tropospheric ozone $\left(\mathrm{O}_{3}\right)$ (Goode et al., 2000; Chan et al., 2003). Moreover, biomass burning emissions include some greenhouse gases $\left(\mathrm{CO}_{2}, \mathrm{CH}_{4}, \mathrm{~N}_{2} \mathrm{O}\right)$ that alter the climate and air quality (Langmann et al., 2009; Lapina et al., 2006; Simpson et al., 2006). Quantification of the influence of boreal forest fires on the Earth-atmosphere system and on the climate has become one of the key topics for the scientific community.

Forest fires in the boreal regions of Siberia, Canada, and Alaska peak during the period from May to October (Lavoué et al., 2000). Some studies highlight the increase in the number of boreal forest fires and the total forested area burned over Canada during the past 3 decades, corresponding to increasing temperatures and reduced moisture in this area (Gillett et al., 2004; Rinsland et al., 2007; Marlon et al., 2008). Wotton et al. (2010) estimate an increase of $30 \%$ in boreal forest fire occurrence by 2030 , causing a possible growth of $30 \%$ in the emission of $\mathrm{CO}_{2}$ and other greenhouse gases (Amiro et al., 2009). The effects of boreal biomass burning emissions on the $\mathrm{O}_{3}$ concentration have been investigated by several authors, with some studies showing situations where $\mathrm{O}_{3}$ concentrations increase and others where it is unaffected (e.g. Wofsy et al., 1992; Jacob et al., 1992; Mauzerall et al., 1996; Wotawa and Trainer, 2000; Val Martin et al., 2006; Real et al., 2007; Leung et al., 2007; Jaffe and Wigder, 2012; Parrington et al., 2012). The analysis of the ARCTAS-B (NASA Arctic Research of the Composition of the Troposphere from Aircraft and Satellites) aircraft measurements of biomass burning plumes in central Canada in the spring and summer of 2008 showed consistent production of peroxyacetyl nitrate (PAN), with little evidence of $\mathrm{O}_{3}$ formation, and, in some plumes, the $\mathrm{O}_{3}$ mixing ratios measured within boreal biomass burning plumes were indistinguishable from measurements outside of the plumes (Alvarado et al., 2010). The production of ozone $P\left(\mathrm{O}_{3}\right)$ measured in boreal fire plumes has been reported to be a function of the plume age (Parrington et al., 2013), but with mixed, nonconclusive results. For example, boreal fire plumes transported over the Azores and measured between 1 and 2 weeks after emission showed an $\mathrm{O}_{3}$ increase between 40 and $90 \%$ (Val Martin et al., 2006; Pfister et al., 2006). On the other hand, observations over Siberia in 2006 of aged boreal fire plumes (up to a week) showed some plumes with $\mathrm{O}_{3}$ en-

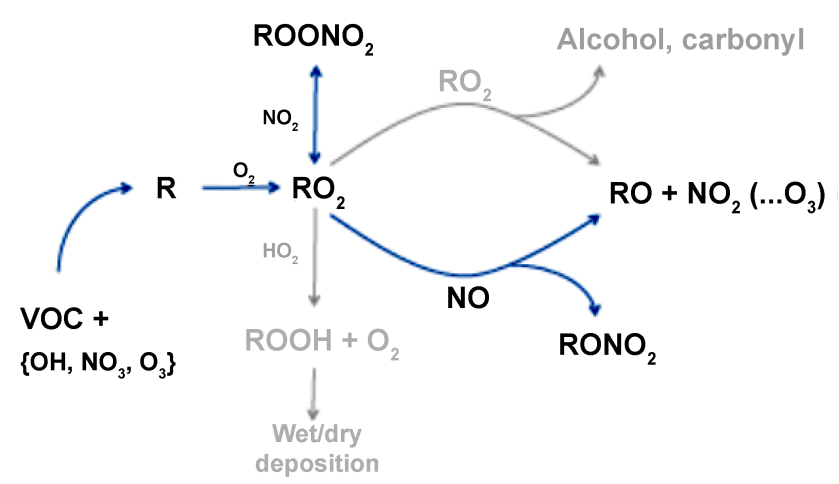

Figure 1. A schematic of the atmospheric chemical system (Atkinson and Arey, 2003; Palmer et al., 2013).

hancement and others with $\mathrm{O}_{3}$ depletion; on average, the $\mathrm{O}_{3}$ in the fire plumes was not significantly different from that in the background atmosphere (Verma et al., 2009). In earlier studies of relatively fresh plumes (1-2 days), $\mathrm{O}_{3}$ was reported to be enhanced in one-third of the boreal fire plumes, with concentrations in the remaining plumes being unaffected (Wofsy et al., 1992; Mauzerall et al., 1996).

In the atmosphere, volatile organic compounds (VOCs) are oxidized by $\mathrm{OH}, \mathrm{NO}_{3}$, or $\mathrm{O}_{3}$, producing an alkyl radical $\mathrm{R}$ that rapidly reacts with molecular oxygen $\mathrm{O}_{2}$ to form peroxy radicals $\left(\mathrm{HO}_{2}, \mathrm{RO}_{2}\right)$ (Reaction $\left.\mathrm{R} 1\right)$. The $\mathrm{RO}_{2}$, then, can proceed in different ways: (1) reacting with $\mathrm{NO}$ and producing a molecule of alkyl nitrate ( $\sum$ ANs, $\sum \mathrm{RONO}_{2}$ ) (Reaction R2) or an alkoxy radical $\mathrm{RO}$ (Reaction R4) or (2) reacting with $\mathrm{NO}_{2}$ and producing peroxy nitrates $\left(\sum \mathrm{PNs}, \sum \mathrm{ROONO}{ }_{2}\right)$ (Reaction R3). Reactions (R4) and (R3) have opposite effects on the $\mathrm{O}_{3}$ budget, propagating or terminating radical cycles, respectively. Thus, peroxy nitrate formation competes with the $\mathrm{O}_{3}$ production resulting from Reactions (R4)-(R8). Alkyl nitrate formation via Reaction (R2) can also affect the $\mathrm{O}_{3}$ budget. The reaction cycles that are of interest when considering nitrogen oxides $\left(\mathrm{NO}_{x}\right)$ and odd-hydrogen radicals $\left(\mathrm{HO}_{x}\right)$ (Reactions $\left.\mathrm{R} 1-\mathrm{R} 8\right)$ are illustrated schematically in Fig. 1 and listed below.

$$
\begin{aligned}
& \mathrm{OH}+\mathrm{RH}+\mathrm{O}_{2}+\mathrm{M} \rightarrow \mathrm{RO}_{2}+\mathrm{H}_{2} \mathrm{O}+\mathrm{M} \\
& \mathrm{RO}_{2}+\mathrm{NO}+\mathrm{M} \rightarrow \mathrm{RONO}_{2}+\mathrm{M} \\
& \mathrm{RO}_{2}+\mathrm{NO} \mathrm{NO}_{2}+\mathrm{M} \rightarrow \mathrm{RO}_{2} \mathrm{NO}_{2}+\mathrm{M} \\
& \mathrm{RO}_{2}+\mathrm{NO} \rightarrow \mathrm{RO}+\mathrm{NO}_{2} \\
& \mathrm{RO}+\mathrm{O}_{2} \rightarrow \mathrm{R}^{\prime} \mathrm{C}(\mathrm{O}) \mathrm{R}^{\prime \prime}+\mathrm{HO}_{2} \\
& \mathrm{HO}+\mathrm{NO} \rightarrow \mathrm{OH}+\mathrm{NO}_{2} \\
& \mathrm{NO}_{2}+h v \rightarrow \mathrm{NO}+\mathrm{O}_{2} \\
& \mathrm{O}+\mathrm{O}_{2}+\mathrm{M} \rightarrow \mathrm{O}_{3}+\mathrm{M}
\end{aligned}
$$

The removal processes for the $\sum$ PNs could be (1) thermal dissociation into $\mathrm{NO}_{2}$; (2) UV photolysis; (3) reaction with $\mathrm{OH}$; and (4) deposition. Different investigations have been 
done about the PAN (MPAN, PPN) loss in different environments; for example, Roberts et al. (1998) showed that in a marine boundary layer the likely mechanism for the PAN loss is the deposition in seawater or on aerosol surface. Moreover, Cleary et al. (2007) described the PAN loss processes by thermal decomposition, indicating that its lifetime varies from hours (for a $T>287 \mathrm{~K}$, lower troposphere) to months (for a $T<263 \mathrm{~K}$, mid-high latitude and free troposphere). They measured $\sum$ PNs in order to evaluate the contribution of each individual $\mathrm{PN}\left(\mathrm{PN}_{i}\right)$ to the $\sum \mathrm{PNs}$, observing that individual PNs are in steady state with their aldehydes precursors and that their loss is the thermal decomposition into $\mathrm{NO}_{2}$ and the subsequent reaction of the peroxy radical (PA) with the NO.

In July and August 2011, the BOReal forest fires on Tropospheric oxidants over the Atlantic using Aircraft and Satellites (BORTAS) measurement campaign was carried out in order to quantify the impact of boreal biomass burning on the composition and distribution of tropospheric oxidants. The BORTAS project involved several international institutions with the support of the UK Facility for Airborne Atmospheric Measurements (FAAM). The instruments were installed on board the FAAM British Aerospace (BAe) 146 research aircraft, and the campaign was based at Halifax airport (Nova Scotia, Canada). During the campaign, 15 flights were carried out (nominally referenced as flights B618-B632) in eastern Canada that were planned to maximize the probability of sampling air masses produced from forest fires in Canada (Ontario) or the USA. More detailed information about the BORTAS campaign objectives and preliminary results are presented by Palmer et al. (2013).

The primary aim of this study is to evaluate and understand the impact of the boreal fire emissions during the BORTAS campaign on the formation of $\mathrm{O}_{3}$ and $\sum$ PNs within biomass burning plumes. Our sub-objectives include (i) identification and classification of the plumes through the pyrogenic species analysis; (ii) determination of the sources of the biomass burning plumes using back trajectories; (iii) understanding of the role played by the $\sum$ PNs produced during biomass burning in the $\mathrm{O}_{3}$ budget; and (iv) the estimation of the balance between the production of ozone and the production of $\sum$ PNs in this specific environment.

\section{Instrumental}

A comprehensive description of the BORTAS experiment and of the overall instrumentations involved can be found in Palmer et al. (2013). Here we will describe briefly only the measurements included in this analysis. $\mathrm{NO}_{2}, \sum \mathrm{PNs}$, and $\sum$ ANs were measured using the TD-LIF (thermal dissociation-laser-induced fluorescence) instrument developed at the University of L'Aquila (Italy) (Dari-Salisburgo et al., 2009; Di Carlo et al., 2013). Briefly, this technique permits direct measurement of $\mathrm{NO}_{2}$ molecules excited by laser radiation. The $\sum \mathrm{PNs}$ and $\sum \mathrm{ANs}$ are measured after thermal dissociation into $\mathrm{NO}_{2}$ by heating the air sample at 200 and $400^{\circ} \mathrm{C}$, respectively (Day et al., 2002; Di Carlo et al., 2013). Nault et al. (2015) found that methyl peroxy nitrate $\left(\mathrm{CH}_{3} \mathrm{O}_{2} \mathrm{NO}_{2}\right)$, which can be abundant in particular conditions (very low temperature, below $240 \mathrm{~K}$, typical of the high atmosphere), may contribute interference to highaltitude $\mathrm{NO}_{2}$ measurements resulting from thermal decomposition occurring in the sample intake system. This interference is a function of the intake system temperature and increases from $280 \mathrm{~K}$, at which the interference is negligible, up to $300 \mathrm{~K}$, at which it can be of the order of $10 \%$. During all the BORTAS flights analysed in this paper, the cabin temperature has been kept at about $280 \mathrm{~K}$; as a consequence, the impact on the $\mathrm{NO}_{2}$ of the $\mathrm{CH}_{3} \mathrm{O}_{2} \mathrm{NO}_{2}$ dissociation is negligible. Moreover, this species is not expected to be significant in our study, since the ambient temperatures of the air masses sampled during the period in analysis range between 250 and $280 \mathrm{~K}$ and the $\mathrm{CH}_{3} \mathrm{O}_{2} \mathrm{NO}_{2}$ concentration is significant only for temperatures lower than $240 \mathrm{~K}$. The measurements of $\mathrm{O}_{3}$ were carried out with an UV absorption system Model 49C (Thermo Environmental Corp.) (Wilson and Birks, 2006). CO was measured using a vacuum UV (VUV) resonancefluorescence system (Gerbig et al., 1999). A chemiluminescence instrument equipped with a photolytic converter was also used to measure $\mathrm{NO}$ and $\mathrm{NO}_{2}$ (Lee et al., 2009; Reidmiller et al., 2010). VOC concentrations were measured by the University of York using a WAS (whole-air sampling) system coupled to an offline GC-FID (gas chromatography with flame ionization detector) (Hopkins et al., 2003; Purvis et al., 2013) and by the University of East Anglia using a proton transfer reation-mass spectrometer (PTR-MS; Murphy et al., 2010). Observed compounds and a complete list of the instruments on board the BAe 146 aircraft during the BORTAS campaign with accuracy and detection limit are reported in Palmer et al. (2013).

\section{Data analysis}

\subsection{Geographical location and meteorological situation}

Figure 2 shows the geographic coverage of the five flights selected for our analysis. The flights were carried out between 12 July and 3 August 2011 over Canada and, in particular, above the North Atlantic Ocean, Nova Scotia, Maine, and Québec. The altitude during the flights exceeded a typical planetary boundary layer depth of $2000 \mathrm{~m}$ a.s.l. so that local emissions do not affect the measurements, especially those carried out in the fire plumes. The specific features of each BORTAS flight and a description of the meteorology associated with them can be found in Palmer et al. (2013). The synoptic situations of the fire plume flights analysed in this work are similar to those of background flights (Palmer et al., 2013). 


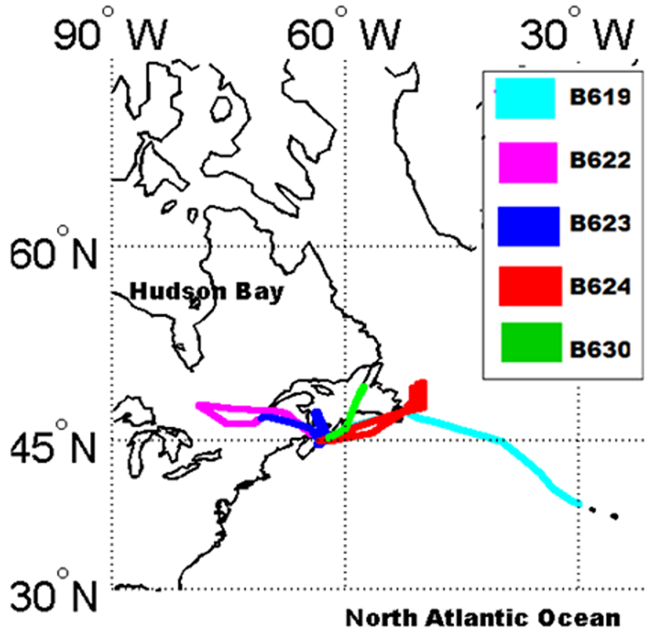

Figure 2. FAAM146 flight tracks during July 2011. The different colours are the tracks of each different flight: during B623 and B624 fire plumes were observed, during B619 and B630 background air was measured, and during B622 fire plume and background air were detected.

\subsection{Identification of the plumes: vertical profiles and back trajectories}

$\mathrm{CO}$ is a product of incomplete combustion (Crutzen et al., 1979; Andreae and Merlet, 2001; Lewis et al., 2013); therefore it is one of the tracers used to classify the plumes emitted by boreal fires. However, it is necessary to discriminate between anthropogenic and biomass burning $\mathrm{CO}$ emissions; for this purpose, following Lewis et al. (2013), we defined a CO threshold of $200 \mathrm{ppbv}$ and verified at the same time the presence of other pyrogenics such as furfural or camphor to confirm the fire origin of the plume. In conclusion, we classify the air masses in three classes: (1) those sampled within boreal biomass burning plumes ( $\mathrm{CO} \geq 200 \mathrm{ppbv})$ with significant presence of other pyrogenic species such as furfural or camphor (Andreae and Merlet, 2001; Lewis et al., 2013); (2) those impacted by anthropogenic emissions $(C O \geq 200 \mathrm{ppb}$ without the presence of furfural or camphor); and (3) those sampled in background conditions $(\mathrm{CO}<200 \mathrm{ppb})$. Using the above criteria to distinguish between flights where we sampled fire plumes and those when we sampled background air, we analysed the vertical profiles of species known to have a significant biomass burning source, such as $\mathrm{NO}_{2}, \Sigma \mathrm{PNs}, \sum \mathrm{ANs}, \mathrm{CO}, \mathrm{O}_{3}$, and some VOCs (i.e. propene, methacrolein, acetylene, benzene, ethylbenzene, toluene, o-xylene, benzaldehyde, furfural, and camphor). The $\mathrm{CO}$ and pyrogenic species analysis allows us to select five flights in which we distinguish between those where we sampled boreal fire emissions (B622, B623, and B624 - labelled henceforth "plume" flights) and those in which we measured background air (B619, B622, and B630 - labelled henceforth "background" flights). Flight B622 is a

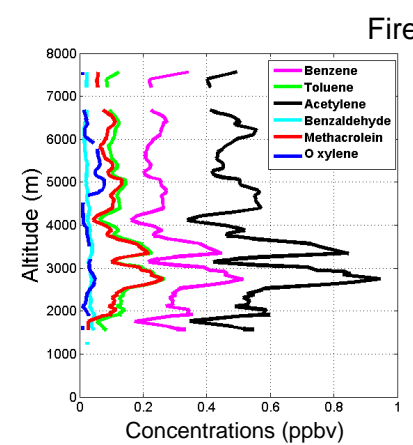

Fire plume
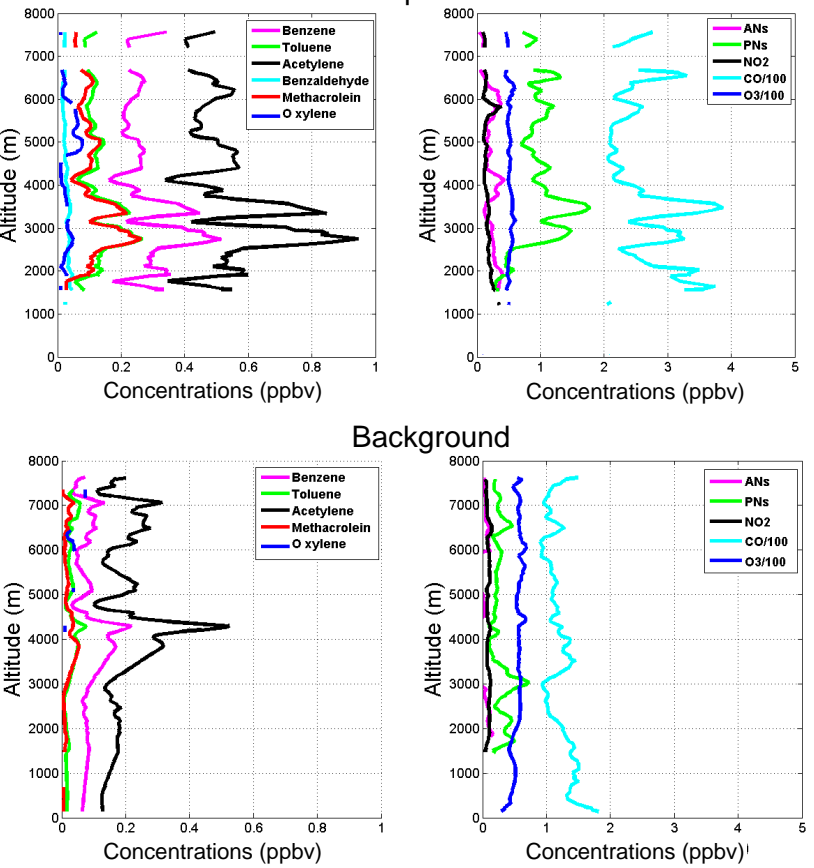

Background

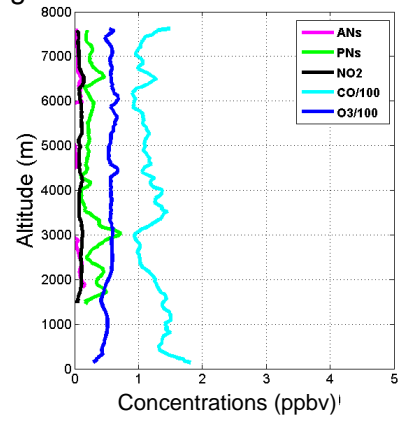

Figure 3. Vertical profiles of benzene, toluene, acetylene, methacrolein, and o-xylene (panels on the left), and $\sum \mathrm{AN}, \sum \mathrm{PN}$, $\mathrm{NO}_{2}, \mathrm{CO}$, and $\mathrm{O}_{3}$ (panels on the right) concentrations averaged for the plume flights (upper panels: B622, B623, B624 flights) and the background flights (lower panels: B619, B622, B630 flights).

particular case in which both conditions are met, and we split this flight into two different parts: plume and background. Figure 3 shows profiles of the species indicated above as a function of the altitude for the plume flights (upper panels) and for the background flights (lower panels). It is possible to observe in Fig. 3 that the vertical structures are different in the two conditions. In the upper panels (plume flights) the concentrations of some species - especially CO, $\Sigma$ PNs, acetylene, and benzene - show significant and concomitant increases at 3500 and $6000 \mathrm{~m}$ a.s.l.. Moreover, in the plume measurements at $2000 \mathrm{~m}$ a.s.l. a large increase in the $\mathrm{CO}$ levels is measured concurrent with an increase in the $\sum$ PNs smaller than at the other altitudes. This suggests that the conditions of the air masses at $2000 \mathrm{~m}$ a.s.l. are more complex and that it potentially has various origins, i.e. impacted both by anthropogenic and boreal biomass burning emissions. The $\sum \mathrm{AN}$ concentrations are lower than the $\sum \mathrm{PN}$ concentrations and do not show significant structures. The $\mathrm{O}_{3}$ profile shows little variability between 1000 and $7000 \mathrm{~m}$ altitude with no concentration changes that coincide with variations in $\mathrm{CO}$. In the background flights, as expected, the concentrations of the species analysed do not show strong vertical structures such as in the plume flights, with the exception of VOCs that show a peak at about $4 \mathrm{~km}$. 

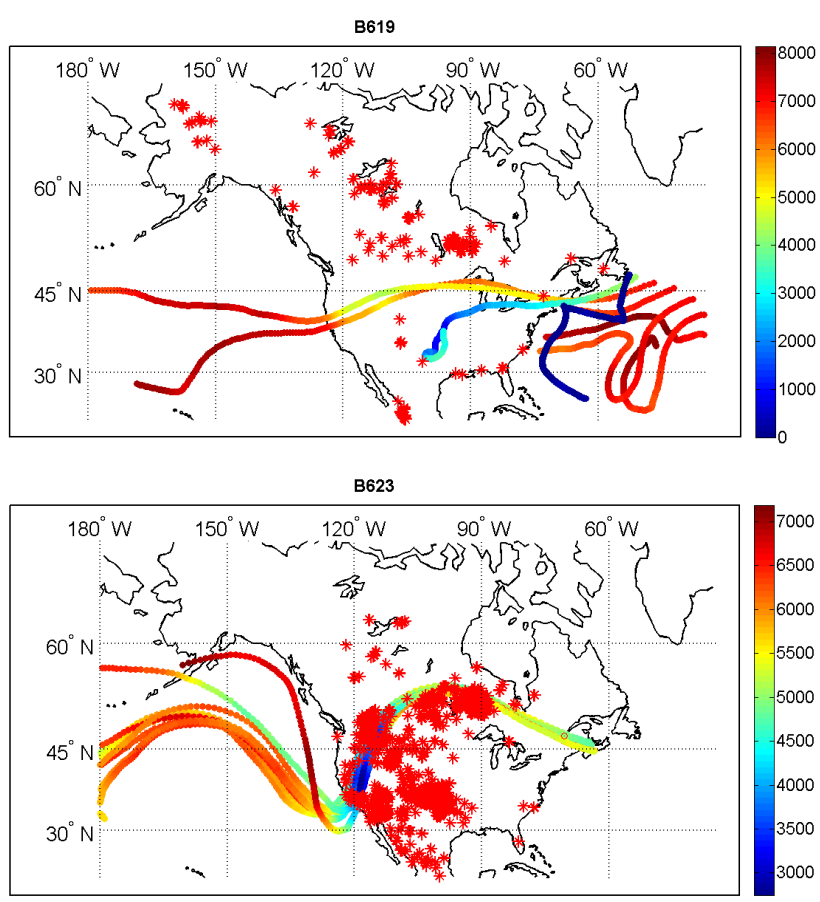

Figure 4. Location of the boreal biomass burning activity during the BORTAS campaign recorded by the FLAMBE inventory (red asterisks) and air mass backward trajectory analysis starting from location along the flight trajectories. Flight B623 (lower panel) sampled multiple fire plumes, whereas flight B619 (upper panel) was representative of background conditions.

To facilitate the determination of the sources of the biomass burning plumes (Tereszchuk et al., 2011; Parrington et al., 2012), we calculated Lagrangian back trajectories using the Hybrid Single Particle Lagrangian Integrated Trajectory (HYSPLIT) model (Draxler et al., 1999) to verify the origin of the air masses. The Fire Locating And Monitoring of Burning Emissions (FLAMBE) archive provides fire emission data from 2000 to the present worldwide (Reid et al., 2009), incorporating active fire detection data from geostationary and polar-orbiting satellites. To locate the sources of the boreal biomass burning plumes measured during the BORTAS campaign, the FLAMBE inventory data have been used in conjunction with the HYSPLIT back trajectories. In Fig. 4, 8-day back trajectories are evaluated starting from points along the flight track, and the corresponding fires (red asterisks) from the FLAMBE archive are shown for the plume flight B619 (upper panel) and for the background flight B623 (lower panel). The same analysis has been done for all the flights of the campaign, although here we report only the results of flights B619 and B623 since they are representative of all the other flights. Parrington et al. (2013) evaluated the photochemical age of the air masses for each flight using the ratio of $\log$ (n-butane / ethane) and assuming an $\mathrm{OH}$ concentration of $2 \times 10^{6}$ molecules $\mathrm{cm}^{-3}$. They found that the age calculated for the air masses sampled within the boreal biomass burning emissions ranges between 1 and 5 days and that the background air is older than 6 days.

Their results are in agreement with the back-trajectory analysis, confirming that the air masses sampled during the plume flights crossed biomass fires during the previous 8 days and, conversely, that the background air masses do not overlap with fires up to 8 days before. In addition, Griffin et al. (2013) investigated boreal fire plumes during the BORTAS campaign using back trajectories calculated by the Canadian Meteorological Centre (CMC) and showed that the boreal fire plume that originated from forest fires is approximately 1.5 days old, which is in agreement with the age calculated for the air masses sampled within the boreal biomass burning emissions.

\subsection{Chemical signatures of plumes}

In Figure 5 the time series of $\mathrm{NO}_{2}, \sum \mathrm{PNs}, \sum \mathrm{ANs}, \mathrm{O}_{3}, \mathrm{CO}$, and furfural (when measured) for the B619 flight (panel a) and the B630 flight (panel b) are shown. During these background flights, the concentrations of all the species measured remain quite stable. The $\sum$ PN concentrations are significantly greater than those of $\sum$ ANs but lower compared to those measured in the plume flights (less than $0.5 \mathrm{ppb}$ ). Moreover, $\sum$ PNs do not show the significant structure that is shown in the $\mathrm{O}_{3}$ measurements. $\mathrm{CO}$ is substantially lower than the $200 \mathrm{ppb}$ threshold, with the exception of one peak measured during B619 during a period spent in the airport for refuelling (at ground level) where the CO level is affected by anthropogenic emissions and increases, reaching a maximum of about $300 \mathrm{ppb}$ during take-off.

The B622 flight (Fig. 5b) shows two regimes, as indicated by the $\mathrm{CO}$ concentrations and by the furfural measurements. In the first part of the flight (between 2000 and $4000 \mathrm{~m}$ a.s.l., highlighted by a grey box in Fig. 5b) the CO levels (cyan line) exceed $150 \mathrm{ppb}$ and the furfural (yellow line) shows three big plumes (up to $1.2 \mathrm{ppb}$ ) in which the $\sum$ PNs also increase (reaching the maximum value of $3.5 \mathrm{ppb}$ ). On the other hand, in the second part of the flight the $\mathrm{CO}$ and $\sum \mathrm{PNs}$ decrease and the furfural is below the detection limit, indicating that the air sampled is not affected by biomass burning. It is interesting to observe that $\mathrm{O}_{3}$ and $\mathrm{NO}_{2}$ concentrations are quite stable when flying within or outside of the fire plume. Flight B623 (Fig. 5c) represents a case in which the air masses sampled for most of the flight were impacted by biomass burning emissions, and the remaining air masses show influence from human activities. In fact, $\mathrm{CO}$ levels are also always greater than $200 \mathrm{ppb}$, and the furfural is below the detection limit during the whole flight, indicating an anthropogenic origin of the air masses. The fire plumes (highlighted by grey boxes) are characterized by sharp increases in the $\mathrm{CO}$ concentrations (maximum value of $552 \mathrm{ppb}$ ) and in the $\sum \mathrm{PN}$ concentrations (maximum value of $1.5 \mathrm{ppb}$ ) measured while flying at a constant altitude of about $4000 \mathrm{~m}$ a.s.l. In the final part of flight B623 (between 00:26 and 01:00 UTC) a vertical 

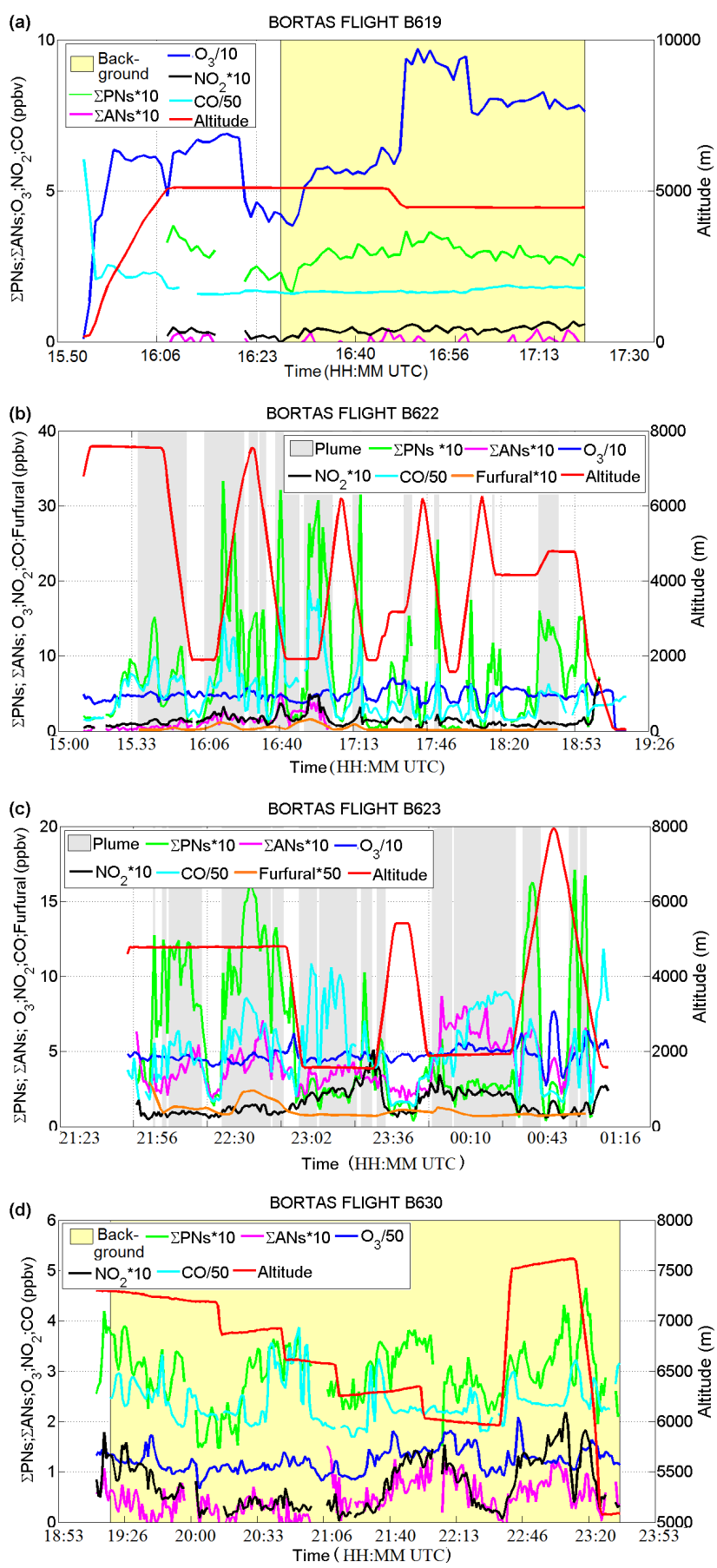

Figure 5. Time series of the $\sum \mathrm{PNs}, \sum \mathrm{ANs}, \mathrm{NO}_{2}, \mathrm{O}_{3}, \mathrm{CO}$, furfural (ppbv) measured during the flights in this analysis: the flights B619 (a) and B630 (d) were background plumes, flight B622 was in part impacted by fire plume and in part by no fire (b), and flight B623 (c) was affected by fire plume. Time is reported in Coordinated Universal Time (UTC).

spiral was carried out flying from 2000 up to $8000 \mathrm{~m}$ a.s.l. In this leg, plumes originating from different fires (identified analysing the HYSPLIT back trajectories) were sam-

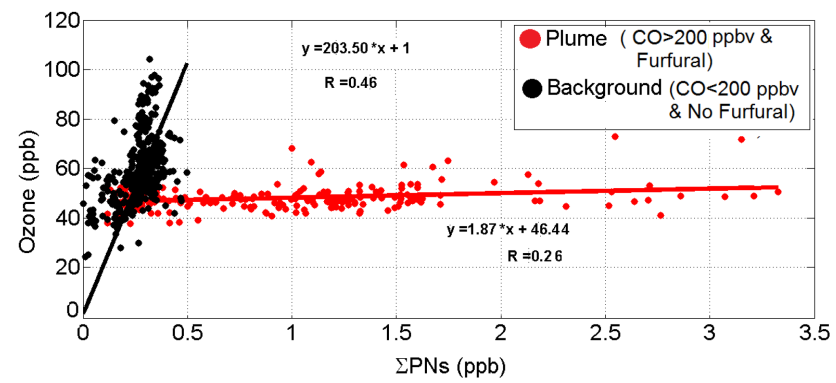

Figure 6. Scatter plot between measured $\mathrm{O}_{3}$ and measured $\sum \mathrm{PNs}$ for the flights B619, B622, B623, B624, and B630. Straight line is best-fit linear regression. Plume identification follows the methodology and the analysis described in Sect. 3.2 and reported in the legend.

pled. At about $4000 \mathrm{~m}$ a.s.l., back trajectories showed that the air masses sampled had the same origin as the fire plumes sampled at the same altitude in the first part of the flight. Both plumes were characterized by high levels of $\sum$ PNs (up to $1.7 \mathrm{ppb})$. At the top of the spiral (8000 m a.s.l.), an aged plume was encountered with low $\sum \mathrm{PN}$ concentrations and quite high $\mathrm{O}_{3}$ concentrations (about $60 \mathrm{ppb}$ ). This high $\mathrm{O}_{3}$ concentration represents the highest value measured during the whole flight.

According to the back trajectories, this air mass originated from fires in the western states of the USA (Oregon, Montana, Washington, Idaho, California, Nevada).

\section{4 $\sum$ PNs and ozone}

The connection between $\mathrm{O}_{3}$ and $\sum \mathrm{PNs}$ is highlighted by the scatter plot of ozone vs. $\sum$ PN mixing ratios in Fig. 6. Two different dependences can be identified, distinguishing the air masses that are representative of the background environment (flight B619, and part of B622 and B630) and those emitted or influenced by emissions from biomass burning (flights B623 and B624, and part of B622). We distinguished between the plume and the background flights as described in Sect. 3.2: that is, based on the CO threshold $(\gtrless 200 \mathrm{ppb})$ and the pyrogenic species analysis. The linear fit of the data influenced by biomass burning emissions has a slope of $\sim 1.87 \mathrm{O}_{3} \mathrm{ppb} / \sum \mathrm{PNs}$ ppb compared to $\sim 203.5$ of the linear fit of background data, which indicates the important role played by the $\sum$ PNs in the sequestration of ozone precursors in air masses influenced by fire emissions. This can be quantified by calculating the productions of $\mathrm{O}_{3}$ and $\sum \mathrm{PNs}$, following the $\sum \mathrm{AN}$ production schemes introduced by Atkinson (1985) and applied in other studies (Perring et al., 2010). This approach excludes the contribution of $\sum$ ANs for two reasons: (1) AN concentrations are very low in our observations strongly impacted by boreal biomass burning, so their contribution is negligible; (2) to isolate the role of $\sum$ PNs from that of $\sum$ ANs in the $\mathrm{O}_{3}$ that may dominate 
Table 1. Species involved in the calculation of peroxy nitrate and ozone production, their weighted reaction constant with $\mathrm{OH}\left(k^{*}\right.$ expressed in $\mathrm{cm}^{3} \mathrm{~s}^{-1}$; see the text on how it is calculated), and the $\Sigma$ PN branching ratio $(\alpha)$.

\begin{tabular}{lll}
\hline Species & $k^{*}$ & $\alpha$ \\
\hline Methacrolein & $1.48 \times 10^{-11}$ & 0.2777 \\
Acetylene & $2.37 \times 10^{-13}$ & 0.3084 \\
Benzene & $4.16 \times 10^{-14}$ & 0.3084 \\
Ethylbenzene & $1.82 \times 10^{-13}$ & 0.3084 \\
Toluene & $1.97 \times 10^{-13}$ & 0.3084 \\
o-Xylene & $7.29 \times 10^{-12}$ & 0.3084 \\
Benzaldehyde & $1.36 \times 10^{-11}$ & 0.3084 \\
CO & $2.39 \times 10^{-13}$ & 0 \\
\hline
\end{tabular}

in particular observations, like those reported here. We applied the same technique for the calculation of the PN production, defining the branching ratio for the peroxy nitrates as $\alpha=k_{\mathrm{R} 3} /\left(k_{\mathrm{R} 3}+k_{\mathrm{R} 4}\right)$. Therefore, the $\sum \mathrm{PN}$ production is given by $\alpha\left(\mathrm{OH}+\mathrm{RH}+\mathrm{O}_{2}+\mathrm{NO}_{2} \rightarrow \mathrm{H}_{2} \mathrm{O}+\mathrm{RO}_{2} \mathrm{NO}_{2}\right)$, and the $\mathrm{O}_{3}$ production is described as $(1-\alpha)\left(\mathrm{RH}+4 \mathrm{O}_{2}+h v \rightarrow\right.$ $\left.\mathrm{H}_{2} \mathrm{O}+\mathrm{R}^{\prime} \mathrm{C}(\mathrm{O})+2 \mathrm{O}_{3}\right)$. In this description we made the approximation of neglecting the impact of $[\mathrm{NO}] /\left[\mathrm{NO}_{2}\right]$ in the $\alpha$ calculation following Seefeld et al. (1997) that showed how the relative yield $(\alpha)$ of the PAN has a linear dependency on the ratio between the $\mathrm{NO}$ and the $\mathrm{NO}_{2}$. This is true for $[\mathrm{NO}] /\left[\mathrm{NO}_{2}\right]$ varying between 0 and 3.5 indicating that the ratio between $k_{\mathrm{R} 3}$ and $k_{\mathrm{R} 4}$ is constant with respect to this ratio. In our cases, $[\mathrm{NO}] /\left[\mathrm{NO}_{2}\right]$ is significantly lower than 3.5 ; therefore we can neglect the impact of $[\mathrm{NO}] /\left[\mathrm{NO}_{2}\right]$ in the $\alpha$ calculation. Moreover, they demonstrated that the ratio between $k_{\mathrm{R} 3}$ and $k_{\mathrm{R} 4}$ is independent from the temperature and varies between $\sim 0.04$ and $\sim 0.47$, and our result, $\sim 0.31$ (see Table 1), is in agreement with their observations.

The production terms can be written as

$$
\begin{aligned}
P\left(\sum \mathrm{PNs}\right)= & \sum_{i} \alpha_{i} k_{\mathrm{OH}+\mathrm{RH}_{\mathrm{i}}}[\mathrm{OH}][\mathrm{VOCs}], \\
P\left(\mathrm{O}_{3}\right)= & \sum_{i} 2\left(1-\alpha_{i}\right) k_{\mathrm{OH}+\mathrm{RH}_{\mathrm{i}}}[\mathrm{OH}][\mathrm{VOCs}] \\
& +k_{\mathrm{OH}+\mathrm{CO}[\mathrm{OH}][\mathrm{CO}]}
\end{aligned}
$$

where we considered the weighted sum of the contribution of each VOC to the $\sum \mathrm{PN}$ and to the $\mathrm{O}_{3}$ production. For the $\mathrm{O}_{3}$ we take into account also the $\mathrm{CO}$ contribution on the $P\left(\mathrm{O}_{3}\right)$ because of significant emissions associated with biomass burning.

In our analysis, we use two approaches to estimate the production of the $\sum \mathrm{PNs}$ and $\mathrm{O}_{3}$ : (1) a direct calculation considering the contribution to the $\mathrm{PN}$ and $\mathrm{O}_{3}$ production of all the VOCs, among those measured during BORTAS, that produce a PN species after first- or second-order reactions of the VOC oxidation by $\mathrm{OH}$; in this case we considered only the production of $\sum$ PNs and $\mathrm{O}_{3}$ neglecting their losses; (2) a simulation using a box model based on the Master Chem-

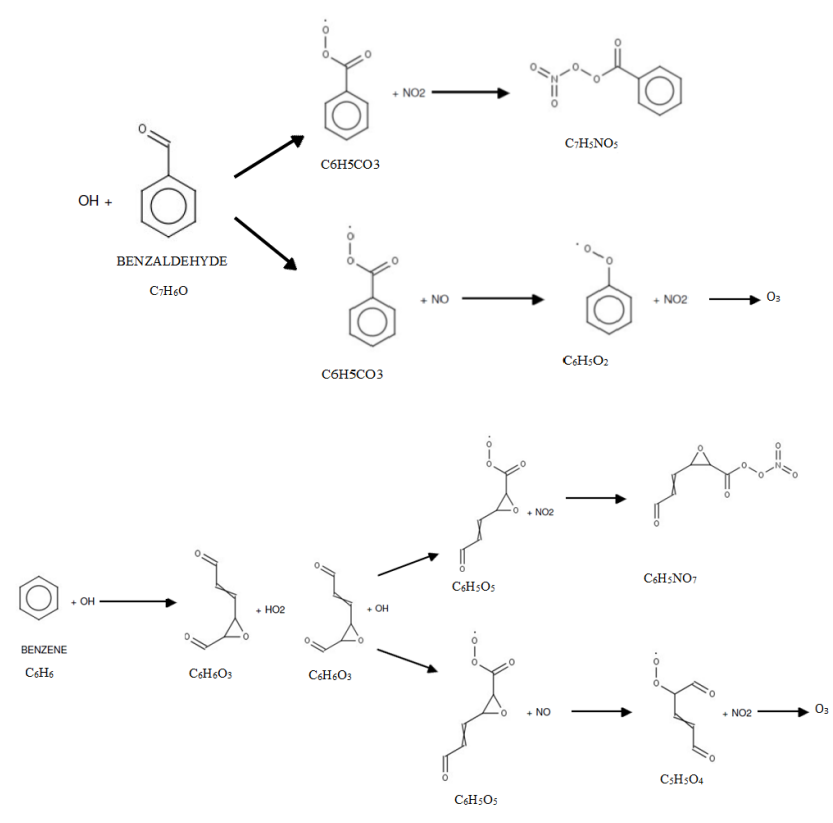

Figure 7. Examples of oxidation schemes that are common to all the VOCs that have as products $\mathrm{PNs}_{\mathrm{N}}$ and $\mathrm{O}_{3}$. Upper panel: structural formula of the oxidation of benzaldehyde that directly produces perbenzoyl nitrate $\left(\mathrm{C}_{7} \mathrm{H}_{5} \mathrm{NO}_{5}\right)$ and $\mathrm{O}_{3}$. Lower panel: structural formula of the oxidation of benzene that produces $\mathrm{O}_{3}$ and indirectly the $\mathrm{PN}\left(\mathrm{C}_{6} \mathrm{H}_{5} \mathrm{NO}_{7}\right)$.

ical Mechanism (MCM) where all the measured VOCs are used as input compounds to evaluate in output the production of $\mathrm{PNs}$ and $\mathrm{O}_{3}$; in the model simulations we considered the net production of $\sum \mathrm{PNs}$ and $\mathrm{O}_{3}$ (that is, the production minus the loss). The mechanism used to calculate directly the $\sum \mathrm{PN}$ and $\mathrm{O}_{3}$ production is similar for all the VOCs; therefore we illustrate as an example the production mechanism of the perbenzoyl nitrate $\left(\mathrm{C}_{7} \mathrm{H}_{5} \mathrm{NO}_{5}\right)$, derived from the firstorder oxidation of the benzaldehyde $\left(\mathrm{C}_{7} \mathrm{H}_{6} \mathrm{O}\right)$ (Fig. 7, upper panel), and the production of the $\mathrm{PN}\left(\mathrm{C}_{6} \mathrm{H}_{5} \mathrm{NO}_{7}\right)$, generated by the second-order oxidation of the benzene (Fig. 7, lower panel). In the first case, abstraction of the aldehydic hydrogen by $\mathrm{OH}$ followed by $\mathrm{O}_{2}$ addition forms an acyl peroxy radical $\left(\mathrm{C}_{7} \mathrm{H}_{5} \mathrm{O}_{3}\right)$. The acyl peroxy radical can react either with $\mathrm{NO}_{2}$, forming the perbenzoyl nitrate, or with $\mathrm{NO}$, producing $\mathrm{C}_{6} \mathrm{H}_{5} \mathrm{O}_{2}$ and $\mathrm{NO}_{2}$ (Fig. 7, upper panel). In the second case, the production of PN starts with the benzene oxidation by $\mathrm{OH}$ forming three different products: $11.8 \%$ of these reactions generate benzene-1,3,5-triol $\left(\mathrm{C}_{6} \mathrm{H}_{6} \mathrm{O}_{3}\right)$ and $\mathrm{HO}_{2}$. The benzene-1,3,5-triol oxidation by $\mathrm{OH}$, in turn, produces a molecule of $\mathrm{C}_{6} \mathrm{H}_{5} \mathrm{O}_{5}$ in $31 \%$ of cases that finally reacts with $\mathrm{NO}_{2}$ to form the peroxy nitrate $\mathrm{C}_{6} \mathrm{H}_{5} \mathrm{NO}_{7}$ or with $\mathrm{NO}$, generating $\mathrm{C}_{5} \mathrm{H}_{5} \mathrm{O}_{4}$ plus $\mathrm{NO}_{2}$ (Fig. 7, lower panel). For the branch of benzene oxidation that produces $\mathrm{PN}$ it is necessary to weight the contribution of the VOC oxidation to the PN formation by applying a branching ratio of 0.118 to the reaction constant for the initial benzene oxidation by $\mathrm{OH}$ and 
Table 2. Concentrations of each species involved in the $\sum \mathrm{PN}$ and $\mathrm{O}_{3}$ production (all reported in ppt), the production terms $P\left(\mathrm{O}_{3}\right)$ and $P\left(\sum \mathrm{PNs}\right)$ (expressed in ppt s $\left.{ }^{-1}\right)$, and their ratios $P\left(\mathrm{O}_{3}\right) / P\left(\sum \mathrm{PNs}\right)$ for all the flights analysed. All the species reported in this table are used for the MCM model calculation of $P\left(\mathrm{O}_{3}\right)$ and $P\left(\sum \mathrm{PNs}\right)$. The selected flights are distinguished between the flights where we sampled boreal fire emissions (part of B622, B623 and B624 - labelled "plume" flights) and those in which we measured background air (B619, part of B622 and B630 - labelled "background" flights).

\begin{tabular}{|c|c|c|c|c|c|c|c|}
\hline & Parameters & B619 & B622 & B630 & B622 & B623 & B624 \\
\hline 1 & Ethane & 1094.0 & 1209.8 & 975.1 & 4705.0 & 2407.5 & 1919.6 \\
\hline 2 & Propane & 225.0 & 270.4 & 186.0 & 1141.2 & 563.4 & 432.3 \\
\hline 3 & n-Butane & 42.9 & 53.7 & 36.9 & 258.7 & 133.4 & 89.8 \\
\hline 4 & i-Butane & 16.8 & 17.9 & 18.6 & 73.3 & 36.7 & 33.8 \\
\hline 5 & n-Pentane & 14.5 & 18.7 & 10.1 & 106.2 & 46.1 & 34.7 \\
\hline 6 & i-Pentane & 9.6 & 16.7 & 5.6 & 37.6 & 19.3 & 47.7 \\
\hline 7 & n-Hexane & 11.0 & 8.0 & 6.3 & 49.4 & 21.0 & 12.7 \\
\hline 8 & 2+3-Methylpentane & 5.0 & 6.6 & 39.4 & 19.4 & 7.5 & 10.4 \\
\hline 9 & n-Heptane & 6.0 & 9.9 & 6.8 & 35.1 & 13.5 & 8.8 \\
\hline 10 & n-Octane & 4.8 & 5.4 & 6.2 & 26.0 & 10.3 & 5.1 \\
\hline 11 & Ethene & 419.0 & 585.4 & 67.2 & 5115.2 & 2038.4 & 452.5 \\
\hline 12 & Propene & 27.1 & 27.4 & 10.1 & 1127.6 & 179.8 & 14.7 \\
\hline 13 & 1-Butene & 7.7 & 9.1 & 5.3 & 185.0 & 31.4 & 7.3 \\
\hline 14 & Trans-2-butene & 4.0 & 4.3 & 4.5 & 3.3 & 4.8 & 6.1 \\
\hline 15 & i-Butene & 6.0 & 6.1 & 6.8 & 84.1 & 12.2 & 6.5 \\
\hline 16 & 1-Pentene & 5.3 & 11.4 & 2.6 & 56.7 & 10.0 & - \\
\hline 17 & Trans-2-pentene & 2.0 & 4.8 & 4.9 & 16.1 & 3.4 & - \\
\hline 18 & 1,3-Butadiene & 28.3 & 17.1 & 21.4 & 399.1 & 88.9 & 27.5 \\
\hline 19 & Isoprene & 20.5 & 347.5 & 130.4 & 2796.3 & 763.0 & 231.0 \\
\hline 20 & Acetylene $^{1}$ & 256.3 & 208.8 & 156.6 & 2053.6 & 887.8 & 480.4 \\
\hline 21 & Benzene $^{1}$ & 115.5 & 81.1 & 51.6 & 1387.0 & 776.0 & 291.4 \\
\hline 22 & Toluene $^{1}$ & 46.4 & 18.7 & 11.6 & 636.2 & 282.0 & 72.6 \\
\hline 23 & O-Xylene ${ }^{1}$ & 12.3 & 7.9 & 43.2 & 68.6 & 22.5 & 10.8 \\
\hline 24 & $\mathrm{~m}+\mathrm{p}$-Xylene & 33.6 & 20.6 & 36.0 & 117.8 & 42.8 & 12.2 \\
\hline 25 & E-Benzene $^{1}$ & 19.9 & 13.1 & 35.3 & 90.6 & 97.6 & 19.9 \\
\hline 26 & Benzaldehyde $^{1}$ & - & 26.0 & - & 68.0 & 30.5 & 88.6 \\
\hline 27 & Acetophenone & - & 51.8 & - & 44.0 & 46.2 & 312.3 \\
\hline 28 & Acetone & 1692.1 & 1959.9 & 2144.8 & 5561.7 & 3166.5 & 3594.0 \\
\hline 29 & Methyl vinyl ketone & - & 319.7 & - & 4126.0 & - & 62.2 \\
\hline 30 & Methacrolein ${ }^{1}$ & 22.5 & 20.4 & 4.0 & 754.5 & 213.3 & 100.6 \\
\hline 31 & Methanol & 2119.0 & 2731.7 & 1549.9 & 6369.9 & 3950.8 & 4677.3 \\
\hline 32 & Limonene & - & 15.0 & - & 14.3 & - & 14.3 \\
\hline 33 & $\alpha$-Pinene & - & 29.1 & - & 18.5 & 17.5 & 19.3 \\
\hline 34 & Furfural & - & 19.4 & - & 157.5 & 46.5 & 14.4 \\
\hline 35 & Camphor & - & 18.5 & - & 26.2 & 15.5 & 15.3 \\
\hline 36 & $\mathrm{NO}_{2}$ & 40.2 & 108.8 & 73.0 & 507.3 & 137.1 & 153.9 \\
\hline 37 & $\mathrm{O}_{3}$ & 71824.8 & 48217 & 61195 & 42431.0 & 45425 & 50858 \\
\hline 38 & $\sum \mathrm{PNs}(\mathrm{ppt})$ & 288.5 & 281.9 & 298.2 & 2981.2 & 1543.2 & 407.8 \\
\hline 39 & $\sum \mathrm{ANs}(\mathrm{ppt})$ & 148.9 & 72.3 & 46.9 & 404.8 & 399.8 & 335.0 \\
\hline \multirow[t]{3}{*}{40} & $\mathrm{CO}(\mathrm{ppt})$ & 84887.4 & 119559.0 & 119040 & 984590 & 419000 & 251540 \\
\hline & $P\left(\mathrm{O}_{3}\right)\left(\mathrm{ppt} \mathrm{s}^{-1}\right)^{2}$ & 0.0420 & 0.0593 & 0.0581 & 0.5082 & 0.2120 & 0.1379 \\
\hline & $P\left(\sum \mathrm{PNs}\right)\left(\mathrm{ppt} \mathrm{s}^{-1}\right)^{2}$ & $\begin{array}{r}2.9719^{1} \\
10^{-4}\end{array}$ & $\begin{array}{r}4.6631^{1} \\
10^{-4}\end{array}$ & $\begin{array}{r}2.5807^{1} \\
10^{-4}\end{array}$ & 0.0078 & 0.0023 & 0.0017 \\
\hline \multirow[t]{3}{*}{41} & $\frac{P\left(\mathrm{O}_{3}\right)}{p\left(\sum \mathrm{PNs}\right)} 2$ & 141.3 & 127.2 & 225.0 & 65.0 & 90.3 & 78.9 \\
\hline & $P\left(\mathrm{O}_{3}\right)\left(\mathrm{ppt} \mathrm{s}^{-1}\right)$ & 0.5133 & 1.8446 & 0.5554 & 5.5643 & 0.6263 & 0.2432 \\
\hline & $P\left(\sum \mathrm{PNs}\right)\left(\mathrm{ppt} \mathrm{s}^{-1}\right)$ & 0.0035 & 0.0163 & 0.0053 & 0.1182 & 0.0341 & 0.0041 \\
\hline 42 & $\frac{P\left(\mathrm{O}_{3}\right)}{p\left(\sum \mathrm{PNs}\right)}$ & 145.6 & 113.5 & 105.4 & 47.1 & 18.3 & 58.8 \\
\hline
\end{tabular}

${ }^{1}$ Species used for the direct calculation of the production using the product between reaction constants and concentrations of the single species. ${ }^{2} \mathrm{\Sigma PN}$ and $\mathrm{O}_{3}$ production quantified with the model simulation. 
of 0.31 for the following benzene-1,3,5-triol oxidation: hereinafter we indicate the $\mathrm{OH}$ reaction constant weighted following this method as $k^{*}$. The same procedure has been applied also to the other VOCs that do not directly produce peroxy nitrates. Table 1 summarizes all the species involved in the evaluation of the $\sum \mathrm{PN}$ and $\mathrm{O}_{3}$ production during all the flights, indicating for each of them the $\mathrm{OH}$ reaction constant $k^{*}$ and the branching ratio calculated as $\alpha=k_{\mathrm{R} 3} / k_{\mathrm{R} 3}+k_{\mathrm{R} 4}$.

The reaction constants were extracted from the MCM model data or the references therein; from this, the branching ratios $\left(\alpha=k_{\mathrm{R} 3} /\left(k_{\mathrm{R} 3}+k_{\mathrm{R} 4}\right)\right)$ were calculated. For the branching ratio of methacrolein, the value of $k_{\mathrm{R} 4}$ is $(8.70 \times$ $\left.10^{-12}\right) \exp (290 / T)$, where $T$ is the temperature, and $k_{\mathrm{R} 3}$ was evaluated following the MCM model procedure that takes into account the ambient pressure. For the other species, the $k_{\mathrm{R} 4}$ reaction constant is $\left(7.50 \times 10^{-12}\right) \exp (290 / T)$, where $T$ is the ambient temperature, and $k_{\mathrm{R} 3}$ was evaluated as for methacrolein.

The simulation to retrieve the production of $\sum \mathrm{PNs}$ and $\mathrm{O}_{3}$ was carried out using a 0-D photochemical box model (UW Chemical Model, UWCM) that is based on the MCM version v3.2 (http://mcm.leeds.ac.uk/MCM/) into a MATLABbased source code (Wolfe and Thornton 2011). The MCM is a nearly explicit reaction set including primary, secondary, and radical species and about 17000 reactions to tracks all oxidation processes and products throughout the photochemical degradation of VOCs. The inorganic chemistry has also been included in the simulations. The photolysis reactions constants have been estimated from the TUV model (http: //cprm.acd.ucar.edu/Models/TUV/). The model has been initialized using both the meteorological parameters (T, P, RH, and $\mathrm{J}$ values) and the chemical concentrations of $\mathrm{NO}, \mathrm{NO}_{2}$, $\mathrm{OH}$ (fixed at $2 \times 10^{6}$ molecules $\mathrm{cm}^{-3}$, as for the direct calculation), $\mathrm{CO}, \mathrm{O}_{3}$, and all the VOCs (see Table 2) measured during the BORTAS campaign. As no $\mathrm{OH}$ measurements were made during the BORTAS campaign, its value was chosen to be representative of a northern midlatitude summertime $\mathrm{OH}$ concentration (Spivakovsky et al., 2000). This assumption was validated by Parrington et al. (2013), carrying out several tests in order to compare the photochemical ages using different $\mathrm{OH}$ concentrations with the transport timescales from the emission source determined by back-trajectory calculations. Table 2 summarizes the mean concentrations of the VOCs and other species used in the simulations, the $\sum \mathrm{PN}$ and $\mathrm{O}_{3}$ production, and their ratio for each flight analysed. The species highlighted with one asterisk have been used also for the direct calculation of $\sum \mathrm{PN}$ and $\mathrm{O}_{3}$ production terms. The quantities highlighted with two asterisks are the production of PNs and $\mathrm{O}_{3}$ calculated directly, while those without asterisks are the $\sum \mathrm{PN}$ and $\mathrm{O}_{3}$ production retrieved from the model simulations.

Figure 8 shows graphically the results summarized in Table 2. It is evident that during the background flights both the VOC and CO concentrations are significantly lower with respect to those measured during the plume flights, as ex-

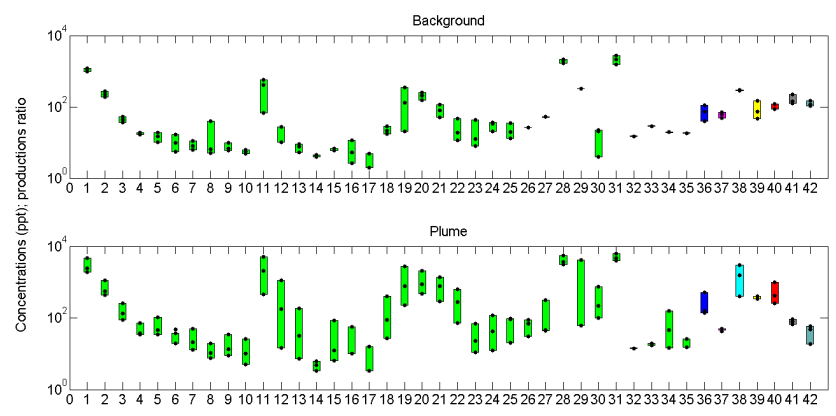

Figure 8. Average concentrations of the species involved in the $\mathrm{O}_{3}$ and $\sum$ PN production. VOCs are in green, $\mathrm{CO}$ in red, $\mathrm{NO}_{2}$ in blue, $\mathrm{O}_{3}$ in magenta, $\sum \mathrm{PNs}$ in cyan, and $\sum \mathrm{ANs}$ in yellow. In grey is reported the ratio between the $P\left(\mathrm{O}_{3}\right)$ and $P\left(\sum \mathrm{PNs}\right)$ evaluated using the direct calculation (see Sect. 3.3); in teal blue is reported the ratio between the $P\left(\mathrm{O}_{3}\right)$ and $P\left(\sum \mathrm{PNs}\right)$ evaluated using the model simulation. The upper panel shows data measured during background flights (B619, part of B622, B630); the lower panel shows data from fire plume flights (part of B622, B623, B624). The parameters shown in this figure are numbered according to Table 2.

pected. At the same time, however, the $\mathrm{O}_{3}$ does not show significantly different concentrations in the biomass burning plumes. Conversely $\sum \mathrm{PN}$ concentrations in the fire plumes increase to a level 3 times higher than the measurements in background air masses, and the alkyl nitrates double. Analysing the measured concentrations of $\mathrm{O}_{3}$ and $\sum \mathrm{PNs}$, we deduced that the boreal biomass burning emissions affect the $\sum \mathrm{PN}$ production more (on average 12 times higher in the fire plume compared with the background air) than the $\mathrm{O}_{3}$ production, which increase by only 5 times in the fire plume. Using the MCM simulation, we got a slightly different increase of $\sum \mathrm{PN}$ production in the fire plume (on average 7 times), whereas the $\mathrm{O}_{3}$ production in the fire plume on average increases 2 times. Therefore in the fire plumes sampled during the BORTAS campaign, with both methods we observed more production of $\mathrm{NO}_{x}$ reservoir species, which can be transported and potentially impact the $\mathrm{O}_{3}$ concentrations in other locations. Alvarado et al. (2010), using a global chemical-transport model, estimated that $40 \%$ of the initial $\mathrm{NO}_{x}$ emission from boreal forest fires was converted into PAN. Since PAN is one of the compounds included in the $\sum$ PN family, our results show that more production of $\sum$ PNs in fire plumes compared with background air is plausible. Moreover, calculating the ozone and peroxy nitrate production ratio (Fig. 6), we found that it is lower in the fire plumes than in the background samples. This suggests that the production of peroxy nitrates during the boreal biomass burning becomes a significant process compared with the ozone production, at least in cold air when the thermal dissociation of $\sum$ PNs is not efficient. For example PAN, which is usually the most abundant $\sum \mathrm{PN}$, has a lifetime strongly dependent on temperature: $1 \mathrm{~h}$ at $300 \mathrm{~K}, 2$ days at $273 \mathrm{~K}$, and 118 days at $250 \mathrm{~K}$ (Isaksen, 1988). In order to understand the 
impact of a specific category of VOCs, we calculated the contribution of each VOC species and $\mathrm{CO}$ to the $\sum \mathrm{PN}$ and $\mathrm{O}_{3}$ production for the fire plume flights (B622, B623, and B624). We found that the ozone production, as expected, is dominated by $\mathrm{CO}$ (with percentages exceeding $93 \%$ for all the flights). Moreover, the production of peroxy nitrates is dominated by methacrolein (with percentages ranging between 38 and $86 \%$ ), followed by benzaldehyde (47-7\%) and o-xylene (19-3\%). An unusual case, in terms of the peroxy nitrate production, is the background flight (B630) during which $75 \%$ of $P\left(\sum \mathrm{PNs}\right)$ is derived from o-xylene and only $13 \%$ from methacrolein, which dominates on all the other flights analysed in this study. At first look this is strange because methacrolein is one of the major products of isoprene oxidation and it is expected that air masses coming from boreal forests (burning or not) would be characterized by high concentrations of biogenic VOCs rather than o-xylene, which is an anthropogenic VOC. Lai et al. (2013) found that at Taipei International Airport (Taiwan) the most abundant VOC produced by the aircraft exhaust emissions is o-xylene. During the B630 flight the altitude was about 7000 ma.s.l. (ranging between 7500 and $6000 \mathrm{~m}$ a.s.l.), higher than the other flights (1700-6000 ma.s.1.), and the flight track was around the eastern coast of Canada: Nova Scotia and Newfoundland Island. At the flight altitude of B630 it is possible to sample air masses affected by aircraft emissions, and so it is likely that the o-xylene dominance on the $\sum \mathrm{PN}$ production can be explained by emissions from aircraft traffic.

Finally, the analysis of the $\mathrm{O}_{3}$ and $\sum \mathrm{PN}$ production in different environments (background and boreal biomass burning plumes) indicates the impact on the tropospheric $\mathrm{O}_{3}$ budget of the fire emissions. In fact, the air masses influenced by biomass burning emissions show a lower (about 90 with the direct method and about 40 with the model $) \frac{P\left(\mathrm{O}_{3}\right)}{p\left(\sum \mathrm{PNs}\right)}$ ratio with respect to that for the background air masses (about 180 with the direct method and about 120 with the model), suggesting that the ozone production in the fire plumes is less significant than the peroxy nitrate formation, contrary to what occurs in the background air masses. The difference between the calculated ratios and the measured $\mathrm{O}_{3} / \sum \mathrm{PNs}$ (see Fig. 6) can be explained considering that (1) the air masses are not fresh emissions and that (2) the $\sum \mathrm{PN}$ production (term at the denominator) is underestimated, as expected since we are not considering all the possible VOC precursors but only those available for the BORTAS campaign. Moreover, the higher VOC and $\sum$ PN concentrations measured during the fire plume flights, associated with stable $\mathrm{O}_{3}$ levels in the two environments, are indicative of processed air masses (produced 4-5 days before) and suggest that $\mathrm{NO}_{2}$ reservoir species are produced in these plumes and transported to other regions.

\section{Conclusions}

During the BORTAS aircraft campaign in Canada, we analysed the $\sum \mathrm{PN}$ and $\mathrm{O}_{3}$ production in two different environments (air masses affected by fire emissions and those representative of background air) using different approaches: (1) a direct calculation in which we considered the VOC oxidation rate constant and the $\sum \mathrm{PN}$ branching ratios for all the VOC species that produce PN after the first- or second-order reaction of their oxidation by $\mathrm{OH}$; (2) using a 0-D photochemical model based on MCM that includes a detailed chemistry of all the VOCs measured. Comparing the production of $\sum \mathrm{PNs}$ and $\mathrm{O}_{3}$ in plumes impacted by fire emissions with that in background air, we found that, on average, $\sum$ PN production is more strongly enhanced than $\mathrm{O}_{3}$ production: 5-12 times versus 2-7 times. Boreal biomass burning plumes observed during the BORTAS campaign show minimal enhancement of the $\mathrm{O}_{3}$ and $\mathrm{NO}_{2}$ concentrations and slight enhancement of the $\mathrm{O}_{3}$ production. However, they show significant enhancement in both concentration and production of $\sum \mathrm{PNs}$, which can act as a reservoir and enhance ozone production downwind of the plume.

Acknowledgements. The BORTAS project was supported by the Natural Environment Research Council (NERC) under grant number NE/F017391/1. Mark Parrington was supported by the NERC grant. Paul I. Palmer acknowledges support from his Philip Leverhulme Prize.

Edited by: R. MacKenzie

\section{References}

Alvarado, M. J., Logan, J. A., Mao, J., Apel, E., Riemer, D., Blake, D., Cohen, R. C., Min, K.-E., Perring, A. E., Browne, E. C., Wooldridge, P. J., Diskin, G. S., Sachse, G. W., Fuelberg, H., Sessions, W. R., Harrigan, D. L., Huey, G., Liao, J., Case-Hanks, A., Jimenez, J. L., Cubison, M. J., Vay, S. A., Weinheimer, A. J., Knapp, D. J., Montzka, D. D., Flocke, F. M., Pollack, I. B., Wennberg, P. O., Kurten, A., Crounse, J., Clair, J. M. St., Wisthaler, A., Mikoviny, T., Yantosca, R. M., Carouge, C. C., and Le Sager, P.: Nitrogen oxides and PAN in plumes from boreal fires during ARCTAS-B and their impact on ozone: an integrated analysis of aircraft and satellite observations, Atmos. Chem. Phys., 10, 9739-9760, doi:10.5194/acp10-9739-2010, 2010.

Amiro, B. D., Cantin, A., Flannigan, M. D., and De Groot, W. J.: Future emissions from Canadian boreal forest fires, Can. J. Forest Res., 39, 383-395, doi:10.1139/X08-154, 2009.

Andreae, M. O. and Merlet, P.: Emission of trace gases and aerosols from biomass burning, Global Biogeochem. Cy., 15, 955-966, 2001.

Atkinson, R. and Arey, J.: Atmospheric degradation of volatile organic compounds, Chem. Rev., 103, 4605-4638, 2003. 
Atkinsons, R.: Kinetics and mechanisms of the gas-phase reactions of the hydroxyl radical with organic compounds under atmospheric conditions, Chem. Rev., 85, 89-201, 1985.

Bond, T. C., Streets, D. G., Yarber, K. F., Nelson, S. M., Woo, J. H., and Klimont, Z.: A technology-based global inventory of black and organic carbon emissions from combustion, J. Geophys. Res.-Atmos., 109, D14203, doi:10.1029/2003jd003697, 2004.

Bowman, D. M. J. S., Balch, J. K., Artaxo, P., Bond, W. J., Carlson, J. M., Cochrane, M. A., D’Antonio, C. M., DeFries, R. S., Doyle, J. C., Harrison, S. P., Johnston, F. H., Keeley, J. E., Krawchuk, M. A., Kull, C. A., Marston, J. B., Moritz, M. A., Prentice, I. C., Roos, C. I., Scott, A. C., Swetnam, T. W., van der Werf, G. R., and Pyne, S. J.: Fire in the earth system, Science, 324, 481-484, 2009.

Chan, C. Y., Chan, L. Y., Harris, J. M., Oltmans, S. J., Blake, D. R., Qin, Y., Zheng, Y. G., and Zheng, X. D.: Characteristics of biomass burning emission sources, transport, and chemical speciation in enhanced springtime tropospheric ozone profile over Hong Kong, J. Geophys. Res., 108, 4015, doi:10.1029/2001JD001555, 2003.

Cleary, P. A., Wooldridge, P. J., Millet, D. B., McKay, M., Goldstein, A. H., and Cohen, R. C.: Observations of total peroxy nitrates and aldehydes: measurement interpretation and inference of OH radical concentrations, Atmos. Chem. Phys., 7, 19471960, doi:10.5194/acp-7-1947-2007, 2007.

Crutzen, P. J. and Andreae, M. O.: Biomass burning in the tropics: Impact on atmospheric chemistry and biogeochemical cycles, Science, 250, 1669-1678, 1990.

Crutzen, P. J., Heidt, L. E., Krasnec, J. P., Pollock, W. H., and Seiler, W.: Biomass burning as a source of atmospheric gases $\mathrm{CO}, \mathrm{H}_{2}, \mathrm{~N}_{2} \mathrm{O}, \mathrm{NO}, \mathrm{CH}_{3} \mathrm{Cl}$ and $\mathrm{COS}$, Nature, 282, 253-256, 1979.

Dari-Salisburgo, C., Carlo, P. D., Giammaria, F., Kajii, Y., and D'Altorio, A.: Laser induced fluorescence instrument for $\mathrm{NO}_{2}$ measurements: observations at a central Italy background site, Atmos. Environ., 43, 970-977, 2009.

Day, D. A., Wooldridge, P. J., Dillon, M. B., Thornton, J. A., and Cohen, R. C.: A thermal dissociation laser-induced fluorescence instrument for in-situ detection of $\mathrm{NO}_{2}$, peroxy nitrates, alkyl nitrates, and $\mathrm{HNO}_{3}$, J. Geophys. Res., 107, 4046, doi:10.1029/2001JD000779, 2002.

Di Carlo, P., Aruffo, E., Busilacchio, M., Giammaria, F., DariSalisburgo, C., Biancofiore, F., Visconti, G., Lee, J., Moller, S., Reeves, C. E., Bauguitte, S., Forster, G., Jones, R. L., and Ouyang, B.: Aircraft based four-channel thermal dissociation laser induced fluorescence instrument for simultaneous measurements of $\mathrm{NO}_{2}$, total peroxy nitrate, total alkyl nitrate, and $\mathrm{HNO}_{3}$, Atmos. Meas. Tech., 6, 971-980, doi:10.5194/amt-6-971-2013, 2013.

Draxler, R. R.: HYSPLIT4 user's guide, Tech. Rep. NOAA Tech. Memo. ERL ARL-230, NOAA Air Resources Laboratory, Silver Spring, MD, 1999.

Gerbig, C., Schmitgen, S., Kley, D., Volz-Thomas, A., Dewey, K., and Haaks, D.: An improved fast-response vacuum-UV resonance fluorescence CO instrument, J. Geophys. Res., 104, 1699$1704,1999$.

Gillett, N., Weaver, A. J., Zwiers, F. W., and Flannigan, M. D.: Detecting the effect of climate change on Canadian forest fires, Geophys. Res. Lett., 31, L18211, doi:10.1029/2004GL020876, 2004.
Goode, J. G., Yokelson, R. J., Ward, D. E., Susott, R. A., Babbitt, R. E., Davies, M. A., and Hao, W. M.: Measurements of excess $\mathrm{O}_{3}, \mathrm{CO}_{2}, \mathrm{CO}, \mathrm{CH}_{4}, \mathrm{C}_{2} \mathrm{H}_{4}, \mathrm{C}_{2} \mathrm{H}_{2}, \mathrm{HCN}, \mathrm{NO}, \mathrm{NH}_{3}$, $\mathrm{HCOOH}, \mathrm{CH}_{3} \mathrm{COOH}, \mathrm{HCHO}$ and $\mathrm{CH}_{3} \mathrm{OH}$ in 1997 Alaskan biomass burning plumes by airborne fourier transform infrared spectroscopy (AFTIR), J. Geophys. Res., 105, 22147-22166, 2000.

Griffin, D., Walker, K. A., Franklin, J. E., Parrington, M., Whaley, C., Hopper, J., Drummond, J. R., Palmer, P. I., Strong, K., Duck, T. J., Abboud, I., Bernath, P. F., Clerbaux, C., Coheur, P.F., Curry, K. R., Dan, L., Hyer, E., Kliever, J., Lesins, G., Maurice, M., Saha, A., Tereszchuk, K., and Weaver, D.: Investigation of $\mathrm{CO}, \mathrm{C}_{2} \mathrm{H}_{6}$ and aerosols in a boreal fire plume over eastern Canada during BORTAS 2011 using ground- and satellite-based observations and model simulations, Atmos. Chem. Phys., 13, 10227-10241, doi:10.5194/acp-13-10227-2013, 2013.

Hopkins, J. R., Read, K. A., and Lewis, A. C.: Two column method for long-term monitoring of non-methane hydrocarbons (NMHCs) and oxygenated volatile organic compounds, J. Environ. Monitor., 5, 8-13, 2003.

Jacob, D. J., Wofsy, S. C., Bakwin, P. S., Fan, S.-M., Harriss, R. C., Talbot, R. W., Bradshaw, J., Sandholm, S., Singh, H. B., Gregory, G. L., Browell, E. V., Sachse, G. W., Blake, D. R., and Fitzjarrald, D. R.: Summertime photochemistry at high northern latitudes, J. Geophys. Res., 97, 16421-16431, 1992.

Jaffe, D. A. and Wigder, N. L.: Ozone production from wildfires: a critical review, Atmos. Environ., 51, 1-10, doi:10.1016/j.atmosenv.2011.11.063, 2012.

Isaksen, I. S. A. (Ed.): Tropospheric Ozone: Regional and Global Scale Interactions, D. Reidel Pub. Co., Dordrecht, NATO ASI Series C, Vol. 227, 1988.

Lai, C.-H., Chuang, K.-Y., and Chang, J.-W.: Source apportionment of volatile organic compounds at an international airport, Aerosol Air Qual. Res., 13, 689-698, doi:10.4209/aaqr.2012.05.0121, 2013.

Langmann, B., Duncan, B., Textor, C., Trentmann, J., and van der Werf, G. R.: Vegetation fire emissions and their impact on air pollution and climate, Atmos. Environ., 43, 107-116, 2009.

Lapina, K., Honrath, R. E., Owen, R. C., Val Martın, M., and Pfister, G.: Evidence of significant large-scale impacts of boreal fires on ozone levels in the midlatitude Northern Hemisphere free troposphere, Geophys. Res. Lett., 33, L10815, doi:10.1029/2006GL025878, 2006.

Lavoué, D., Liousse, C., Cachier, H., Stocks, B. J., and Goldammer, J. G.: Modeling of carbonaceous particles emitted by boreal and temperate wildfires at northern latitudes, J. Geophys. Res.-Atmos., 105, 26871-26890, 2000.

Lee, J. D., Moller, D. J., Read, K. A., Lewis, A. C., Mendes, L., and Carpenter, L. J.: Year-round measurements of nitrogen oxides and ozone in the tropical North Atlantic marine boundary layer, J. Geophys. Res., 114, D21302, doi:10.1029/2009JD011878, 2009.

Leung, F.-Y. T., Logan, J. A., Park, R., Hyer, E., Kasischke, E., Streets, D., and Yurganov, L.: Impacts of enhanced biomass burning in the boreal forests in 1998 on tropospheric chemistry and the sensitivity of model results to the injection height of emissions, J. Geophys. Res., 112, D10313, doi:10.1029/2006JD008132, 2007. 
Lewis, A. C., Evans, M. J., Hopkins, J. R., Punjabi, S., Read, K. A., Purvis, R. M., Andrews, S. J., Moller, S. J., Carpenter, L. J., Lee, J. D., Rickard, A. R., Palmer, P. I., and Parrington, M.: The influence of biomass burning on the global distribution of selected non-methane organic compounds, Atmos. Chem. Phys., 13, 851-867, doi:10.5194/acp-13-851-2013, 2013.

Marlon, J. R., Bartlein, P. J., Carcaillet, C., Gavin, D. G., Harrison, S. P., Higuera, P. E., Joos, F., Power, M. J., and Prentice, I. C.: Climate and human influences on global biomass burning over the past two millennia, Nat. Geosci., 1, 69-702, 2008.

Mauzerall, D., Jacob, D. J., Fan, S.-M., Bradshaw, J., Gregory, G., Sachse, G., and Blake, D.: Origin of tropospheric ozone at remote high northern latitudes in summer, J. Geophys. Res., 101, 41754188, 1996.

Murphy, J. G., Oram, D. E., and Reeves, C. E.: Measurements of volatile organic compounds over West Africa, Atmos. Chem. Phys., 10, 5281-5294, doi:10.5194/acp-10-5281-2010, 2010.

Nault, B. A., Garland, C., Pusede, S. E., Wooldridge, P. J., Ullmann, K., Hall, S. R., and Cohen, R. C.: Measurements of $\mathrm{CH}_{3} \mathrm{O}_{2} \mathrm{NO}_{2}$ in the upper troposphere, Atmos. Meas. Tech., 8, 987-997, doi:10.5194/amt-8-987-2015, 2015.

Palmer, P. I., Parrington, M., Lee, J. D., Lewis, A. C., Rickard, A. R., Bernath, P. F., Duck, T. J., Waugh, D. L., Tarasick, D. W., Andrews, S., Aruffo, E., Bailey, L. J., Barrett, E., Bauguitte, S. J.B., Curry, K. R., Di Carlo, P., Chisholm, L., Dan, L., Forster, G., Franklin, J. E., Gibson, M. D., Griffin, D., Helmig, D., Hopkins, J. R., Hopper, J. T., Jenkin, M. E., Kindred, D., Kliever, J., Le Breton, M., Matthiesen, S., Maurice, M., Moller, S., Moore, D. P., Oram, D. E., O'Shea, S. J., Owen, R. C., Pagniello, C. M. L. S., Pawson, S., Percival, C. J., Pierce, J. R., Punjabi, S., Purvis, R. M., Remedios, J. J., Rotermund, K. M., Sakamoto, K. M., da Silva, A. M., Strawbridge, K. B., Strong, K., Taylor, J., Trigwell, R., Tereszchuk, K. A., Walker, K. A., Weaver, D., Whaley, C., and Young, J. C.: Quantifying the impact of BOReal forest fires on Tropospheric oxidants over the Atlantic using Aircraft and Satellites (BORTAS) experiment: design, execution and science overview, Atmos. Chem. Phys., 13, 6239-6261, doi:10.5194/acp-13-6239-2013, 2013.

Parrington, M., Palmer, P. I., Henze, D. K., Tarasick, D. W., Hyer, E. J., Owen, R. C., Helmig, D., Clerbaux, C., Bowman, K. W., Deeter, M. N., Barratt, E. M., Coheur, P.-F., Hurtmans, D., Jiang, Z., George, M., and Worden, J. R.: The influence of boreal biomass burning emissions on the distribution of tropospheric ozone over North America and the North Atlantic during 2010, Atmos. Chem. Phys., 12, 2077-2098, doi:10.5194/acp-122077-2012, 2012.

Parrington, M., Palmer, P. I., Lewis, A. C., Lee, J. D., Rickard, A. R., Di Carlo, P., Taylor, J. W., Hopkins, J. R., Punjabi, S., Oram, D. E., Forster, G., Aruffo, E., Moller, S. J., Bauguitte, S. J.B., Allan, J. D., Coe, H., and Leigh, R. J.: Ozone photochemistry in boreal biomass burning plumes, Atmos. Chem. Phys., 13, 7321-7341, doi:10.5194/acp-13-7321-2013, 2013.

Perring, A. E., Bertram, T. H., Farmer, D. K., Wooldridge, P. J., Dibb, J., Blake, N. J., Blake, D. R., Singh, H. B., Fuelberg, H., Diskin, G., Sachse, G., and Cohen, R. C.: The production and persistence of $\Sigma \mathrm{RONO}_{2}$ in the Mexico City plume, Atmos. Chem. Phys., 10, 7215-7229, doi:10.5194/acp-10-7215-2010, 2010.
Pfister, G., Emmons, L. K., Hess, P. G., Honrath, R., Lamarque, J.-F., Val Martin, M., Owen, R. C., Avery, M., Browell, E. V., Holloway, J. S., Nedelec, P., Purvis, R., Rywerson, T. B., Sachse, G. W., and Schlager, H.: Ozone production from the 2004 North American boreal fires, J. Geophys. Res., 111, D24S07, doi:10.1029/2006JD007695, 2006.

Purvis, R. M., Lews, A. C., Hopkins, J. R., Andrews, S., and Minaean, J.: Functionalized aromatic compounds within middle troposphere boreal biomass burning plumes, EGU Meeting, 15, 2013-1389, 2013.

Real, E., Law, K. S., Weinzierl, B., Fiebig, M., Petzold, A., Wild, O., Methven, J., Arnold, S., Stohl, A., Huntrieser, H., Roiger, A., Schlager, H., Stewart, D., Avery, M., Sachse, G., Browell, E., Ferrare, R., and Blake, D.: Processes influencing ozone levels in Alaskan forest fire plumes during long-range transport over the North Atlantic, J. Geophys. Res., 112, D10S41, doi:10.1029/2006JD007576, 2007.

Reid, J. S., Hyer, E. J., Prins, E. M., Westphal, D. L., Zhang, J., Wang, J., Christopher, S. A., Curtis, C. A., Schmidt, C. C., Eleuterio, D. P., Richardson, K. A., and Hoffman, J. P.: Global monitoring and forecasting of biomass burning smoke: Description of and lessons from the Fire Locating and Modeling of Burning Emissions (FLAMBE) program, IEEE J. Sel. Top. Appl., 2, 144-162, 2009.

Reidmiller, D. R., Jaffe, D. A., Fischer, E. V., and Finley, B.: Nitrogen oxides in the boundary layer and free troposphere at the Mt. Bachelor Observatory, Atmos. Chem. Phys., 10, 6043-6062, doi:10.5194/acp-10-6043-2010, 2010.

Rinsland, C. P., Dufour, G., Boone, C. D., Bernath, P. F., Chiou, L., Coheur, P.-F., Turquety, S., and Clerbaux, C.: Satellite boreal measurements over Alaska and Canada during JunJul 2004: Simultaneous measurements of upper tropospheric $\mathrm{CO}$, $\mathrm{C}_{2} \mathrm{H}_{6}, \mathrm{HCN}, \mathrm{CH}_{3} \mathrm{Cl}, \mathrm{CH}_{4}, \mathrm{C}_{2} \mathrm{H}_{2}, \mathrm{CH}_{3} \mathrm{OH}, \mathrm{HCOOH}, \mathrm{OCS}$, and SF6 mixing ratios, Global Biogeochem. Cy., 21, GB3008, doi:10.1029/2006GB002795, 2007.

Roberts, J. M, Bertman, S. B., Parrish, D. D., and Fehsenfeld, F. C.: Measurement of alkyl nitrates at Chebogue Point, Nova Scotia during the 1993 North Atlantic Regional Experiment (NARE) intensive, J. Geophys. Res., 103, 13569-13580, 1998.

Seefeld, S., Kinnison, D. J., and Kerr, J. A.: Relative Rate Study of the Reactions of Acetylperoxy Radicals with $\mathrm{NO}$ and $\mathrm{NO}_{2}$ : Peroxyacetyl Nitrate Formation under Laboratory Conditions Related to the Troposphere, J. Phys. Chem. A, 101, 55-59, 1997.

Simpson, I. J., Rowland, F. S., Meinardi, S., and Blake, D. R.: Influence of biomass burning during recent fluctuations in the slow growth of global tropospheric methane, Geophys. Res. Lett., 33, L22808, doi:10.1029/2006GL027330, 2006.

Spivakovsky, C. M., Logan, J. A., Montzka, S. A., Balkanski, Y. J., Foreman-Fowler, M., Jones, D. B. A., Horowitz, L. W., Fusco, A. C., Brenninkmeijer, C. A. M., Prather, M. J.,Wofsy, S. C., and McElroy, M. B.: Three-dimensional climatological distribution of tropospheric $\mathrm{OH}$ : Update and evaluation, J. Geophys. Res., 105, 8931-8980, 2000.

Tereszchuk, K. A., González Abad, G., Clerbaux, C., Hurtmans, D., Coheur, P.-F., and Bernath, P. F.: ACE-FTS measurements of trace species in the characterization of biomass burning plumes, Atmos. Chem. Phys., 11, 12169-12179, doi:10.5194/acp-1112169-2011, 2011. 
Val Martin, M., Honrath, R., Owen, R. C., Pfister, G., Fialho, P., and Barata, F.: Significant enhancements of nitrogen oxides, ozone and aerosol black carbon in the North Atlantic lower free troposphere resulting from North American boreal wildfires, J. Geophys. Res., 111, D23S60, doi:10.1029/2006JD007530, 2006.

Verma, S., Worden, J., Pierce, B., Jones, DB A., Al-Saadi, J., Boersma, F., Bowman, K., Eldering, A., Fisher, B., Jourdain, L., Kulawik, S., and Worden, H.: Ozone production in boreal fire smoke plumes using observations from the Tropospheric Emission Spectrometer and the Ozone Monitoring Instrument, J. Geophys. Res., 114, D02303, doi:10.1029/2008JD010108, 2009.

Wilson, K. L. and Birks, J. W.: Mechanism and elimination of a water vapor interference in the measurement of ozone by UV absorbance, Environ. Sci. Technol., 40, 6361-6367, 2006.

Wofsy, S. C., Sachse, G. W., Gregory, G. L., Blake, D. R., Bradshaw, J. D., Sandholm, S. T., Singh, H. B., Barrick, J. A., Harriss, R. C., Talbot, R. W., Shipham, M. A., Browell, E. V., Jacob, D. J., and Logan, J. A.: Atmospheric chemistry in the Arctic and subarctic: influence of natural fires, industrial emissions, and stratospheric inputs, J. Geophys. Res., 97, 16731-16746, doi:10.1029/92JD00622, 1992.
Wolfe, G. M. and Thornton, J. A.: The Chemistry of AtmosphereForest Exchange (CAFE) Model - Part 1: Model description and characterization, Atmos. Chem. Phys., 11, 77-101, doi:10.5194/acp-11-77-2011, 2011.

Wotawa, G. and Trainer, M.: The influence of Canadian forest fires on pollutant concentrations in the United States, Science, 288, 324-328, 2000.

Wotton, B. M., Nock, C. A., and Flannigan, M. D.: Forest fire occurrence and climate change in Canada, Int. J. Wildland Fire, 19, 253-271, 2010 . 